\title{
Sectorial Perceptions of Parental Involvement: Similarities and Dissimilarities
}

\author{
Yael Fisher \\ Achva Academic College \\ Noga Magen-Nagar, \\ Gordon Academic College \\ Muhammad Abu-Nasra \\ The Hebrew University of Jerusalem \\ Department of sociology and anthropology
}

\begin{abstract}
The study examined the perceptions of parental involvement among 320 Arab-sectorand 319 Jewish-sector elementary-school teachers in Israel. On a questionnaire listing potential components of the concept, participants indicated the degree of pertinence of each. Findings showed that teachers in both sectors agreed that parental involvement includes three components: pedagogy, control, and resources. Both sectors identified the three most significant parental activities as related to the hiring and firing of teachers, understanding classroom social dynamics, and fundraising for extracurricular activities. A cross-sector conceptualization of the term parental involvement creates a shared language and facilitates public discourse on educational issues.
\end{abstract}

Key words: Parental Involvement; Elementary schools; Teachers' perceptions

The relationship between school and parents has been a debated issue in the last three decades and has yet to be resolved. This relationship is characterized by a combination of expectations and hopes, both of the parents and of the teachers, but it also involves a degree of conflict that cannot be dismissed lightly (Friedman, 2011). Teachers' tendency to have a positive attitude regarding this relationship is typical of society and Western democracies in general, and of Jewish teachers in Israel, specifically (Fisher, 2011). However, very little has been written about the manner in which this relationship is perceived by teachers in the Arab sector Israel. Not only has this issue been overlooked for the most part in the Arab sector, no comparison between the Jewish and Arab sectors has been conducted, to date. The Israeli Ministry of Education attributes great importance to the strengthening of the relationship between school and parents in both the Arab and Jewish education sectors, and indeed has stated that parents are considered full partners in the educational process by means of Director General Code of Bylaws (Ministry of Education, 2004, 2005, 2010). Hence, it is important to understand the attitudes of the teachers and design a policy accordingly. The assumption that there are conceptual differences between the two sectors is based on the understanding that teachers' beliefs and perceptions, much like many other processes, are influenced by prior learning experience and cultural background (Farr, 2010).

The teaching and learning processes of Jewish and Arab (both Christian, Muslim, and Druze) teachers are based on their attitudes towards the cultural background in which they were raised, particularly when it comes to the continuum between individualism and collectivism. 
Jewish teachers have been found to be closer to the individualist end of the spectrum, whereas Muslim Arab teachers were characterized as closer to the collectivist end of the spectrum, and Druze teachers were found in between the two sectors (Eilam, 2003). A number of studies have shown that Arab teachers who studied in teacher education colleges with a mixed population which included Jewish students, underwent a democratization process and experienced Western-style teacher training over the course of their studies. Nevertheless, when they returned to teach in schools in the Arab sector, they also returned to teach according to the cultural norms with which they had been raised (Eilam, 2002, 2003). Once the training was completed and as they began to teach in schools, Muslim Arab teachers who had been exposed to educational models associated with the Western democratic world found that they felt conflicted, since the models that they had learned are partially rejected by traditional Arab society. Counter to the expectations of Jewish Israeli society that Arab teachers become agents of change within traditional Arab society, novice Arab teachers in their first year of teaching do not fulfill this mission (Toren, \& Iliyan, 2013).

Based on the information presented, the current study it intends to examine similarities and differences between the two sectors regarding their perceptions of parental involvement.

\section{Parental Involvement - Definition and Conceptualization}

Over the last two decades, public discussion of parental involvement has focused on its contribution to children's academic achievements (Henderson \& Mapp, 2002; Duch, 2005). However, many of the studies conducted were unable to explain the varying degrees of parents' involvement in the education of their children. The most problematic aspect has been the absence of a clear definition of the term parental involvement, and researchers have defined it according to their own perspectives and studies.

Various terms have been used to describe the relationship between family and school or other types of educational frameworks: relationship, involvement, involvement versus intervention, partnership, cooperation, integration, participation, and empowerment, to mention but a few. The professional literature has described parental involvement as including home behaviors as well as school behaviors. We can also find in the literature other similar dimensions: (a) the location of the family's activities, whether in the home or at school, and (b) the extent of the family's participation in school activities and policies. In regard to parental activity in the home, it is customary to refer to parents' involvement in preparing assignments, providing their children with encouragement and emotional support in issues related to their experience in the educational framework, creating a supportive environment even in situations of failure, monitoring homework, and supporting various academic activities. Regarding parental involvement that takes place within the educational framework, it is customary to refer to activities such as volunteering at school, providing assistance in the classroom, participating in decision-making processes, fundraising, and providing technical assistance (Barton, Drake, Perez, St. Louis, \& George, 2004; Smith, Woblstetter, Kuzin, \& De Pedro, 2011; Greenbaum \& Fried, 2011).

However, in recent years, this assumption has changed and parental involvement in the home (i.e., discussing experiences that took place at school and helping children plan their schoolrelated activities) is considered to be the more effective of the two types, in terms of students' academic achievements (Smith, Woblstetter, Kuzin, \& De Pedro, 2011). In all of these instances, the definition of parental involvement was suggested by one of the involved parties (i.e., teachers, parents, students, or policymakers).

The more traditional conceptualizations of the term refer to the parental activities, without distinguish of the location, such as helping their children do homework assignments and 
frequently attending school functions (Domina, 2005; Epstien, 2002). Some define the term as a spectrum, whereby desired parental involvement can range from baking cakes for school events to supporting and operating self-managed schools. The more recent approaches suggest that parental involvement or parental engagement should refer to more subtle social variables, such as parental expectations and the quality of parent child communication (Jeynes, 2010; 2005).

In the past decade, there has been an attempt to approach parental involvement from the community perspective; this approach tends to replace the traditional term, "parental involvement" with the term "community-school relations" (Epstein, 2002; Schutz, 2006). However, as Schutz (2006) emphasized, perusal of the relevant literature demonstrates that a school-centric perspective persists and, in fact, the focus is mostly on the parents per se and not on the community in general.

Fisher (2011) recently attempted to define parental involvement as a concept based on the perceptions and thoughts of teachers, principals, parents, students, and policymakers. Findings reported that the concept of parental involvement at school is manifested in a wide array of 44 parental activities, related mostly to organizational approaches in the school and beyond school grounds. These activities can be active or passive and can pertain to the school as an organization or to the personal needs of the individual child. These activities are categorized according to four domains: parents' contribution to school resources (participation in committees, raising funds for a particular class or for the entire school, voluntary teaching, etc.); monitoring of processes at school (i.e., criticizing the curricula or the lessons or conducting surprise visits to class); involvement in the realm of pedagogy and lifestyle (attending parent-teacher meetings, questioning grades, or supporting a particular side of a debated issue); and activities related to the school's welfare (accompanying school trips, organizing school fairs, etc.). This type of definition actually encompasses several approaches: the approach that focuses on the location of the activities of involved parents, i.e., activities at home, at school and those related to the relationship between community and school (Smith et al., 2011); the approach that emphasizes the activity itself (Lee \& Bowen, 2006; and the approach that emphasizes the initiator of the activities; specifically, activities initiated by the educational framework are referred to as co-optation and management, while a mutual relationship between parents and the educational framework is viewed as engagement and coalition (Smrekar, Cohen-Vogel, \& Lee, 2010).

\section{Parental Involvement in the Arab Education System}

Very few studies have examined the issue of Arab parents' involvement in Israeli schools (Bishara \& Shachar, 2008; Majadla, 2005). The common conclusion from these studies indicates a low level of parental involvement in the Arab education framework in Israel, which is in complete contrast to the situation in the Jewish educational sector (Bishara, \& Shachar, 2008), although the level of involvement in the former has been increasing over the last decade. Based on the few studies conducted on the subject of parental involvement in the Arab sector in Israel, it appears that parents consider the school responsible for the educational aspects, i.e., students' academic achievements. The recent increase in parental involvement is due to several factors. First, parents put greater emphasis on their children's academic achievements, as they consider education to be an instrument that can lead to socioeconomic improvements on both the individual and the collective level (Abu-Asbah, 2005; Arar \& AbuAsbah, 2007). Furthermore, the increase in the level of parental involvement in the Arab sector is related also to social and cultural changes that the Arab population is undergoing in Israel, and the adoption of democratic values, as a result of the interaction with Jewish society, which is characterized by Western values. An increasingly strong criticism of the Arab education 
system is also due to the students' poor results on international and local examinations as well as on higher education institutes' entrance examinations. An additional factor of course is an increase in the level of education of the parents (Abu-Asbah, 2007).

Despite Arab society's transition from a traditional to a more modern society, a transition characterized by a rise in the population's education level (Abu-Asbah, 2005, 2007) and the adoption of democratic values (Arar \& Rigbi, 2009), the anti-democratic authoritarian culture still dominates in Arab schools, due to the sociocultural milieu in which the Arab schools function (Majadla, 2005). Organizational culture in Arab schools deters Arab parents from becoming involved and participating in the management of the school, and they make do by observing from the sidelines. Although parents' increased awareness of goings-on at school is apparently encouraged to a certain degree, this involvement is limited to the level of information sharing (Majadla, 2005). Another possible explanation for the low levels of parental involvement in this sector is the high social and professional status attributed to teachers. Parents view teachers as the highest source of knowledge and educational authority: consequently, they avoid getting practically involved in the education of their children or the educational management of the school, due to the view that teachers are the ones best suited to carry out these functions. Parents' lack of conviction regarding their right to be involved is yet another factor that contributes to the current scenario, and it is likely coupled with the fear that if they do become involved, in the end they might lose face if they do not manage to attain their goals (Bishara \& Shachar, 2008).

The web of relationships between the Arab school and the parents is characterized by a significant social distance. In other words, parents are aware of what takes place in the school, yet they refrain from participating in its pedagogical or educational management (Majadla, 2005). This pattern of cooperation coincides with the category of "informed parents" (Fisher \& Friedman, 2009). The great social distance between school and parents in the Arab sector is detrimental to the children's education, particularly since this distance increases teachers' sense of frustration and leads to a decline in the students' achievement levels (Friedman, Horowitz, \& Shaliv, 1988). Additional evidence of the detrimental effect of the distance between the parents and the school on students' achievements was demonstrated in the study of Bishara and Shachar (2008), which examined factors that affect a school's efficiency and included the measure of parental involvement in the Israeli Arab and Jewish sectors on students' achievements.

Arab schools generally refrain from involving parents in the professional and pedagogical issues, since they perceive this type of involvement as undermining and invading their professional territory; nevertheless, Arab schools demonstrate an openness towards parents and invite them to share in activities related to the condition of the school facilities. Yet the lack of openness of Arab schools towards parents in other matters creates a sense of unrest, which characterizes the relationship between the two parties, especially due to the importance attributed by parents to the education and academic achievements of their children. It appears that parents and children from the Arab sector attribute a great deal of importance not only to the academic achievements, but also to the prominence of homework assignments as part of these achievements. Arab parents were found to be more involved than their Jewish counterparts were in helping their children in everything related to the homework assignment (Kashti, 2011).

Demographic characteristics of parents from the Arab sector have an effect on their level of involvement. It has been shown that urban parents are more involved in their children's education than parents from rural areas. In addition, parents from a high socioeconomic level were also found to be more involved in their children's education than parents from the low- 
or middle class socioeconomic level. Finally, young parents (between the ages of 21 and 30) were found to be more involved in their children's education than were parents over 40 years old (Majadla, 2005).

The increased disparity between the Jewish and Arab education sectors in Israel is related to the degree of support the schools enjoy from the parents, as well as from local authorities, particularly since the schools themselves have become major players in determining their education budget (Swirski \& Dagan-Buzaglo, 2009). These changes in the budget-allocation method did not help the Arab education sector escape its marginal status, especially since the majority of Arab towns are at the bottom of the socioeconomic scale. More than half of all Arab families (54.3\%) live below the poverty line, and the unemployment percentage in this sector is much higher than in the Jewish sector: specifically, unemployment rates among men are $11 \%$ and $5.4 \%$ in the Arab and Jewish sectors, respectively, and unemployment rates among women are $18 \%$ and $5.8 \%$ in the Arab and Jewish sectors, respectively (Wolfson, 2012).

\section{The Goals of the Study}

Two major goals were defined for this study. The first was to learn about differences between the perceptions of parental involvement among Israeli teachers in the Jewish and Arab education sectors, given that teachers' perceptions are based on their attitudes to the cultural background in which they were raised (Eilam, 2003). While more than a few studies have examined perceptions of parental involvement in the context of the Jewish education sector in Israel, very little is known about the teachers' perceptions regarding the same issue in the Arab sector.

The second goal of the study was to try and validate a comprehensive conceptualization of the perceptions of parental involvement. It is extremely important to create a broad conceptualization that is suitable to all, regardless of one's sectorial affiliation, because educational discourse that is based on common definitions is capable of developing processes for improving the education system.

The assumption of the current study was that differences would be found between the sectors in regard to teachers' perceptions of the components of parental involvement, because - as mentioned earlier - Arab teachers who trained in teacher education colleges that cater to both sectors indeed underwent a process of democratization and Western training; however, upon their return to teach in Arab schools, they also returned to the behaviors characteristic of the culture in which they grew up (Eilam, 2002, 2003). Nonetheless, given the absence of prior studies comparing the two sectors in Israel, the assumption regarding expected differences should be considered exploratory --for the most part. Given that the composition of the Arab population in Israel differs from that of Arab societies in other parts of the world, findings from studies that focused on other Arab populations could not serve as a basis for the assumptions of the current study. 


\section{The Sample}

METHOD

Participants included 639 teachers from both sectors: the distribution of participants' background variables is presented in Table 1.

Table 1. The Research Population

\begin{tabular}{|c|c|c|c|c|}
\hline $\begin{array}{l}\text { Demographic } \\
\text { Variable }\end{array}$ & Characteristic & Arab Sector & Jewish Sector & The Entire Sample \\
\hline \multirow{2}{*}{ Gender } & Male & (121) $37.8 \%$ & (23) $7.2 \%$ & (144) 23.296 \\
\hline & Female & (199) 62.2\% & (296) 7.296 & (495) 77.496 \\
\hline \multirow{5}{*}{ Age } & $20-30$ & (99) 30.996 & (50) $15.7 \%$ & (149) 23.596 \\
\hline & $31-40$ & (129) $40.30 \%$ & (118) 3796 & $(247) 3996$ \\
\hline & $41-55$ & $(79) 24.796$ & (129) 40.496 & (208) 3396 \\
\hline & 56 or older & (7) $2.1 \%$ & (19) 69 & (26) 4.196 \\
\hline & no data & (6) $1.9 \%$ & (3) 0.996 & (9) $0.4 \%$ \\
\hline \multirow{5}{*}{ Education } & Undergraduate & $(222) 69 \%$ & (235) 7396 & $(457) 71.596$ \\
\hline & Master's & (74) 23.396 & (71) $22.3 \%$ & (145) 22.796 \\
\hline & PhD & (3) 0.996 & (2) 1.396 & (5) $0.8 \%$ \\
\hline & Other $^{2}$ & (21) 6.896 & (5) 1.696 & (26) 4.196 \\
\hline & No data & & (6) 1.896 & (6) $0.9 \%$ \\
\hline \multirow{4}{*}{$\begin{array}{l}\text { Number of } \\
\text { Students } \\
\text { Attending }\end{array}$} & $400-700$ & (165) 51.6\% & (314) 98.496 & $(479) 7596$ \\
\hline & $701-1000$ & (77) $24 \%$ & & (77) $12 \%$ \\
\hline & 1001 or more & (30) $9.4 \% 6 \%$ & & (30) 4.796 \\
\hline & No data & $(48) 15 \%$ & (5) 1.696 & (53) 8.396 \\
\hline \multirow{5}{*}{$\begin{array}{l}\text { Years of Teaching } \\
\text { Experience }\end{array}$} & First year & (9) $2.8 \%$ & (17) $5.37 \%$ & (26) 4.196 \\
\hline & $2-5$ & (59) 18.496 & (56) $17.6 \%$ & (115) 18.296 \\
\hline & $6-10$ & (89) 27.896 & (46) 14.496 & (135) 21.396 \\
\hline & 11 or more & (157) $51 \%$ & (199) 62.496 & (356) 56.296 \\
\hline & No data & & (1) 0.396 & (1) $0.2 \%$ \\
\hline \multirow{5}{*}{ Role at School } & Discipline teacher & (152) $47.5 \%$ & (119) 37.396 & (271) 42.896 \\
\hline & $\begin{array}{c}\text { Homeroom } \\
\text { teacher }\end{array}$ & (65) 20.396 & (111) 34.896 & (176) 27.896 \\
\hline & $\begin{array}{c}\text { Homeroom } \\
\text { teacher }+ \\
\text { principal }\end{array}$ & (62) 19.496 & (86) 2796 & (148) 23.496 \\
\hline & & (3) $0.9 \%$ & (1) 0.396 & (4) $0.6 \%$ \\
\hline & & (38) 11.996 & (2) 0.696 & (40) 5.496 \\
\hline \multirow{3}{*}{$\begin{array}{l}\text { Management } \\
\text { Team Members }\end{array}$} & Yes & (60) $18.7 \%$ & (88) $27.6 \%$ & (148) 23.296 \\
\hline & No & (233) $72.8 \%$ & (231) 72.496 & (464) 73.696 \\
\hline & No data & (21) 6.596 & & (27) 3.296 \\
\hline Sector & & $(n=320) 49.6 \%$ & $(\mathrm{n}=319) 50.4 \%$ & \\
\hline
\end{tabular}

2 Senior teacher; teaching license without an academic degree

\section{Research Tool}

The research tool used was a questionnaire titled "Questionnaire for Measuring Teachers' Attitudes regarding Parents' Relationship with the School". Participants received the following explanation:

In the questionnaire, you will find statements describing the relationship between school and the parents. You are requested to indicate the degree to which you agree with each of the statements. Read each statement carefully and circle the number that best reflects the degree to which you agree with the statement, where number five indicates a very strong agreement and the number one indicates complete disagreement with the statement. We wish to emphasize that these statements do not refer to the actual situation as it exists, but rather to the degree to which you feel that the statement coincides with your understanding of the concept of parental involvement. 
There were 44 items on the questionnaire, which had been formulated and conceptualized in an earlier study (Fisher, 2011) that used facet theory (Guttman, 1959). Facet theory is the approach in social sciences that combines study design and data analysis (Levy, 1994; Shye \& Elizur, 1994). In the earlier study, facet theory was selected as the methodological approach due to its advantages for the conceptualization of phenomena. An additional study (Kostelitz, 2013) tested the tool with a sample of 319 elementary-school Israeli teachers and found a high reliability rate of .91 Cronbach's alpha, and exploratory factor analysis (EFA) was also conducted. Thus, this questionnaire served as the major research tool in the current study. Following statistical processes and the elimination of items according to accepted norms, 43 items remained, which together explained $44.23 \%$ of the variance (see Table 2).

\section{The Structure of the Components as Found in the Study by Kostelitz (2013) \\ Table 2. Structure of Components of Parental Involvement Scale}

\begin{tabular}{|c|c|c|c|c|}
\hline $\begin{array}{c}\text { Item } \\
\#\end{array}$ & Item Content & $\begin{array}{l}1^{\text {st }} \text { Factor } \\
\text { Loading }\end{array}$ & $\begin{array}{l}\text { 2nd Factor } \\
\text { Loading }\end{array}$ & $\begin{array}{l}\text { 3. Factor } \\
\text { Loading }\end{array}$ \\
\hline \multicolumn{5}{|c|}{$\begin{array}{l}\text { Factor 1: Pedagogy (14 items; Eigenvalue }=10.612 \text {; Explained Variance: } 24.12 \% \text {; } \\
\alpha=.88)\end{array}$} \\
\hline 31 & Aware of violence-related problems & .32 & 62. & 18. \\
\hline 39 & Helps child prepare for exams & .07 & 81. & -.01 \\
\hline 36 & Helps with homework assignments & .11 & 80. & -.03 \\
\hline 37 & Reviews child's notebooks & .02 & 75. & 01. \\
\hline 42 & $\begin{array}{l}\text { Reviews exams that have been } \\
\text { graded by teacher }\end{array}$ & $08-$ & .72 & 11. \\
\hline 38 & $\begin{array}{l}\text { Involved in handling disciplinary } \\
\text { problems }\end{array}$ & .12 & 69. & 11. \\
\hline 41 & $\begin{array}{l}\text { Involved when child contests a } \\
\text { grade }\end{array}$ & .04 & 64. & 36. \\
\hline 29 & Familiar with the curricula & .21 & 53. & 30. \\
\hline 27 & $\begin{array}{l}\text { Acquainted with teaching staff and } \\
\text { homeroom teacher }\end{array}$ & .34 & 52. & 22. \\
\hline 40 & $\begin{array}{l}\text { supports the child in a disagreement } \\
\text { with the teacher }\end{array}$ & $01-$ & 56. & 35. \\
\hline 28 & $\begin{array}{l}\text { familiar with child's social activities } \\
\text { at school and at home }\end{array}$ & .47 & 54. & 199. \\
\hline 30 & $\begin{array}{l}\text { Familiar with the population } \\
\text { components in the child's class }\end{array}$ & .16 & 48 & 35 . \\
\hline 26 & $\begin{array}{l}\text { Understands classroom social } \\
\text { dynamics }\end{array}$ & -.16 & 23. & 13. \\
\hline 33 & $\begin{array}{l}\text { Familiar with decisions made by the } \\
\text { members of the school staff }\end{array}$ & .26 & 35 . & 35. \\
\hline
\end{tabular}

To enable basic sectorial comparison, the questionnaire was adjusted to match the Arab sector, by eliminating the question that refers to the acceptance of new immigrants, a topic that is not relevant to this sector, and by changing two items related to personal background demographics. Optional answers to the question regarding the school in which the participants teach included state-funded Jewish religious or secular elementary schools, as well as statefunded Jewish religious or secular schools spanning grades one through eight. In the Arab sector, all participants were recruited from public elementary or middle schools, and the sample did not include teachers from private schools. Given that responses to this item were different a priori, it was decided that this information would be excluded from the analysis. The questionnaire intended for teachers in the Arab sector contained an additional question pertaining to the school's geographic location (northern, central, or southern part of the 
country). This item seemed relevant to this sector; in contrast, previous studies conducted in the Jewish educational sector, which found no relationship between the geographic area of residence and the perceptions of parental involvement (Fisher, 2011; Friedman \& Fisher, 2203; Fisher \& Friedman, 2002), indicated that this questionnaire item would not be relevant to the Jewish sector. Hence, data pertaining to this item were not included in the analyses. The background variables examined in this study are presented in Table 1 . The final version of the questionnaire included 42 items related to perceptions of parental involvement and seven additional items related to participants' background variables.

\section{Research Procedure}

The study was conducted in two stages, both of which took place during the school year of 2012. In the first stage, the questionnaire was distributed among elementary-school teachers in the Israeli Jewish sector, and in the second stage it was distributed among teachers in the Israeli Arab sector. The distribution of questionnaires in the Jewish sector was part of a study that examined the relationship between teachers' perceptions of parental involvement and their sense of self-efficacy (Kostelitz, 2013). For the purpose of the current study, only the data relevant to teachers' perceptions of parental involvement were used. Given that findings of the previous study indicated a high rate of reliability for the parental involvement scale (alpha $=$ .91), it was decided that the questionnaire would be distributed also to elementary-school teachers in the Arab education sector. To this end, the questionnaire was translated into Arabic by one of the researchers participating in the current study.

The research assistant contacted in both sectors each of the school's principals and coordinated the date and time for questionnaire distribution. The questionnaires were handed out during teachers' meetings and were collected immediately thereafter. The purposes of the research were explained, and confidentiality was ensured.

In the Jewish sector, 319 questionnaires were distributed and returned; in the Arab sector, 400 questionnaires were distributed and 320 (80\% response rate) were returned. A total of 639 completed questionnaires were obtained.

\section{Statistical Analyses}

Confirmatory factor analysis (CFA) was conducted structural equation modeling (SEM), with the AMOS 18 software program. These methods are powerful statistical tools for examining the relationships between latent constructs, and test a priori hypotheses regarding relationships between observed and latent variables. This methodology takes a confirmatory approach to the analysis of data (Byrne, 2001; Jackson, Gillaspy \& Purc-Stephenson, 2009). Given that CFA is part of the larger family of SEM, it usually plays an essential role in evaluating the measurement model before a structural analysis is conducted. Structural analysis is then used for specifying and estimating models of linear relationships between both observed and latent variables (Jackson et al., 2009; MacCallum \& Austin, 2000). When conducting SEM, the analysis produces an estimated population covariance matrix based on the model specified. A key function of SEM is to assess whether the model produces an estimated matrix consistent with the sample matrix (Tabachnick and Fidell, 2007). This consistency is investigated through various measurement indices of Goodness of Fit. If the Goodness of Fit is adequate, it supports the plausibility of the model specified. Different measures of fit are available and are assessed through different indices such as Comparative Fit Index (CFI), Incremental Fit Index (IFI), Tucker Lewis Index (TLI), and Root Mean Square Error of Approximation (RMSEA), as well as chi square test-statistics. For the CFI, IFI, and TLI indices, values greater than .90 are typically considered acceptable, whereas values greater than .95 indicate a good fit to the data (Byrne 2001; Hu \& Bentler, 1999). For well-specified models, an RMSEA of .06 or less indicates a good fit (Hu \& Bentler, 1999). 
The data were initially screened for univariate and multivariate normality and outliers, using SPSS 18 and AMOS 18. The data set contained missing data that were assumed to be missing completely at random. As some of the features in AMOS would not be available with missing data, analyses initially used an imputed data set. The imputation of missing data was conducted using AMOS's integrated function, which creates a new dataset with complete data. This regression imputation uses linear regression to predict the unobserved values for each case, as a linear combination of the observed values for that same case. Predicted values are then plugged in for the missing values (Arbuckle, 2009). The results in the present study are based on the original dataset with missing data, which showed more or less identical results compared to the imputed set. When AMOS 18 is confronted with missing data, the software performs a state-of-the-art estimation using full information maximum likelihood, instead of relying on ad hoc methods, such as list- or pair-wise deletion (Arbuckle, 2009).

\section{RESULTS}

The following results are based on a previous study (Kostelitz, 2013), which conducted an EFA in the context of Israeli Jewish teachers. That study provided the basis for the analysis of the current study's findings. The findings are presented in two stages. The first stage presents the findings that indicate differences between the perceptions of teacher's in the Jewish and the Arab sectors regarding parental involvement; the second stage presents the findings obtained from the confirmatory factor analysis of the entire sample and of each sector separately.

\section{Sectorial Differences in Teachers' Perception of Parental Involvement}

The differences between the perceptions of teachers from the Jewish sector $(\mathrm{N}=319)$ and those of teachers from the Arab sector $(\mathrm{N}=320)$ regarding parental involvement were analyzed according to the following components identified by means of CFA: involvement in pedagogy, resources, and control. For the purpose of comparison, a one-way MANOVA test was conducted. Analysis indicated a simultaneous and significant sectorial difference $[\mathrm{F}(3,629)=$ 114.79, $\left.P<.001 ; \eta^{2}=.35\right]$. In other words, teachers from the Arab sector demonstrated a stronger perception of these components $(M=3.26, S D=.59)$ than did the teachers from the Jewish sector $(\mathrm{M}=2.98, S D=.57)$. A one-way ANOVA, which was intended to examine the source of the differences, found significant differences in pedagogy $[\mathrm{F}(1,631)=11.56, P<.001$; $\left.\eta^{2}=.03\right]$, resources $\left[\mathrm{F}(1,631)=5.87, P<.001 ; \eta^{2}=.02\right]$, and control $[\mathrm{F}(1,631)=110.40, P<$ $\left..001 ; \eta^{2}=.28\right]$. In other words, teachers from the Arab sector ranked items related pedagogy higher $(\mathrm{M}=3.42, S D=.77)$ than did teachers from the Jewish sector $(\mathrm{M}=3.15, S D=.87)$. In addition, teachers from the Arab sector ranked the components related to monitoring higher $(\mathrm{M}=2.72, S D=.68)$ than did teachers from the Jewish sector $(\mathrm{N}=1.89, S D=.65)$. However, teachers from the Jewish sector ranked items related to resources higher $(\mathrm{M}=3.75, S D=.69)$ than did teachers from the Arab sector $(\mathrm{M}=3.56, S D=.70)$.

\section{Results from the Confirmatory Factor Analysis}

Following the findings from the analysis of variance which indicated significant differences between the sectors' perceptions of the components of parental involvement, it was decided to examine the internal reliability of the structure of the questionnaire, by conducting CFA regarding teachers from the Jewish sector, teachers from the Arab sector, and for the entire sample. This examination was conducted using SEM ${ }^{1}$. Typically, the AMOS model contains two parts: a measurement model and a structural model. In the current study, only the measurement model was examined, as it enables an assessment of CFA. This model categorizes the component factors of the latent variables in terms of the measured manifest variables. The

${ }^{1}$ A detailed description of SEM is presented in the methodology section under Statistical Analyses. 
three latent variables examined in this study were pedagogy, resources, and control, each of which consisted of 13 - 15 statements, which were the manifest variables. The model is based on a calculation of correlation matrices among the manifest variables, thus providing an expression of convergent validity of the manifest variables. If correlation between items that represent a single latent variable are higher than the correlations with items representing other variables in the model, then the measurement model is said to have construct validity. In other words, the factor analysis is confirmed. Figure 1 presents the confirmatory factor analysis of the entire sample.

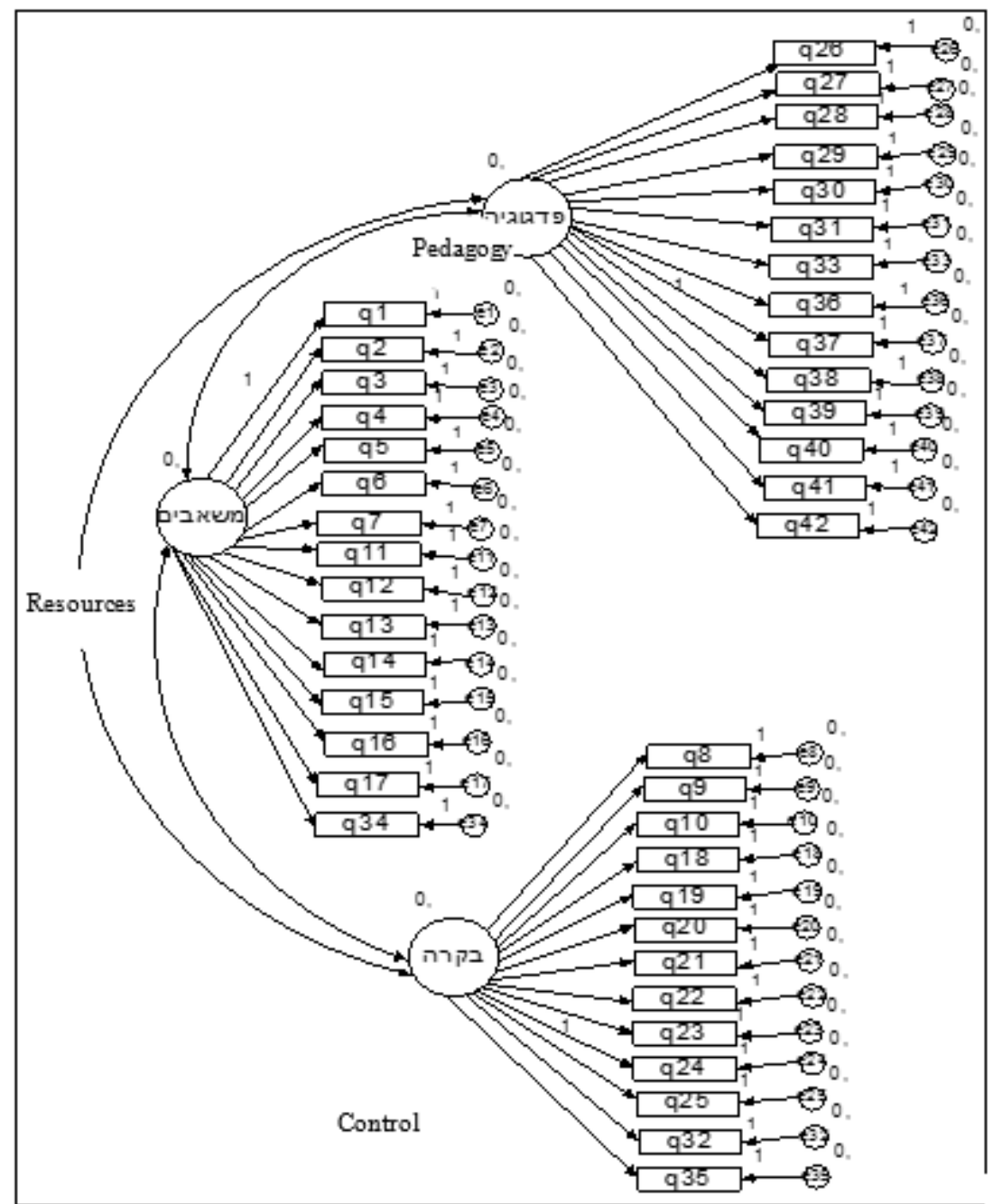

Figure 1. Confirmatory factor analysis "Perception of Parental Involvement"

As mentioned, a major issue in the analysis and assessment of the SEM is the size of the sample on which the analysis of choice is to be conducted. The importance of this feature is due to the fact that the likelihood ratio test of $\chi^{2}$, which examines the model's fit with the data, is sensitive to sample size and requires an acceptable size sample in order to be considered a valid statistical test. If the size of the sample is too small, $\chi^{2}$ could indicate a good fit between the model and the data even if the model is devoid of any theoretical significance. Likewise, if the size of the sample is very large, also a "good" model will be rejected; hence, the efficacy of using this test also with a very large sample is questionable (Hoyle \& Panter, 1995; Kline, 2005). A more reliable measure is $\chi^{2} / \mathrm{df}^{2}$ (Normed $\chi^{2}$ ), for which a value smaller than three $(<3)$ is considered a good fit. In addition to this measure, there are three other measures (see section on Statistical Analyses) that assess the fit between the model and the data: RMSEA, NFI, and 
CFI (Bentler \& Bonett, 1980). A RMSEA value $\leq .05$ indicates a close fit: a value $\geq .08$ indicates a structural error, and a value $>1$ indicates the model should be rejected. The closer the NFI and the CFI values are to one, the better the fit (Bentler, 1992; Byrne, 1989; Hoyle \& Panter, 1995). Table 3 presents the measures of fit (per sector) obtained from the confirmatory factor analysis of the "parental involvement" questionnaire.

Table 3. Measures of Fit for the CFA of the Perceptions of Parental Involvement Scale

\begin{tabular}{|c|c|c|c|}
\hline $\begin{array}{c}\text { Measures of } \\
\text { Fit }\end{array}$ & $\begin{array}{c}\text { Teachers from the } \\
\text { Arab Sector } \\
(\mathbf{N}=\mathbf{3 1 4})\end{array}$ & $\begin{array}{c}\text { Teachers from } \\
\text { the Jewish } \\
\text { Sector } \\
(\mathbf{N}=\mathbf{3 1 9})\end{array}$ & $\begin{array}{c}\text { The Entire Sample } \\
\mathbf{( N = 6 3 3 )}\end{array}$ \\
\hline$/$ df2 $\chi$ & 1.980 & 1.652 & 2.347 \\
\hline CFI & .899 & 942. & 936. \\
\hline NFI & .822 & 871. & 896. \\
\hline RMSEA & .055 & 045. & 045. \\
\hline
\end{tabular}

Findings presented in Table 3 suggest that in the Jewish sector, all three measures of fit RMSEA, $\chi^{2} / \mathrm{df}^{2}$ and CFI, indicated that the model was a good fit, yet the absolute measure of NFI was much smaller than one $(<1)$, indicating that the model does not fit the data. A similar picture emerged regarding the Arab sector, with lower values for the CFI and NFI and higher values for the RMSEA and $\chi^{2} / \mathrm{df}^{2}$ measures, indicating a greater lack of fit of the model with the data. However, examining the model for the entire sample presented a different picture, whereby all the measures of fit indicated that the model for parental involvement provided a good fit for the research data. Therefore, we may conclude that the parental involvement questionnaire has structural validity. Table 4 presents the standard coefficient loadings $(\lambda)$ for the parental involvement model according to sector.

Table 4. Standardized Loading Coefficients $(\lambda)$ of the Model for Validation of the Perceptions of Parental Involvement Scale

\begin{tabular}{|c|c|c|c|c|c|}
\hline \multirow{2}{*}{$\begin{array}{c}\text { The Latent } \\
\text { Variable }\end{array}$} & \multirow{2}{*}{$\begin{array}{c}\text { Item } \\
\#\end{array}$} & \multirow[t]{2}{*}{ The Manifest Variable } & \multicolumn{3}{|c|}{ Standardized Coefficient Loadings $(\lambda)$} \\
\hline & & & $\begin{array}{c}\text { The Entire } \\
\text { Sample } \\
(\mathrm{N}=639)\end{array}$ & $\begin{array}{c}\text { Teachers from } \\
\text { the Arab } \\
\text { Sector } \\
(\mathrm{N}=320)\end{array}$ & $\begin{array}{c}\text { Teachers from } \\
\text { the Jewish } \\
\text { Sector } \\
(\mathrm{N}=319)\end{array}$ \\
\hline \multirow[t]{9}{*}{ Pedagogy } & 26 & $\begin{array}{c}\text { Understanding classroom } \\
\text { social dynamics }\end{array}$ & $0.74^{* * *}$ & $0.67^{* * *}$ & $0.74^{* * *}$ \\
\hline & 27 & $\begin{array}{l}\text { Acquainted with the teaching } \\
\text { staff }\end{array}$ & $0.50^{* * *}$ & $0.46^{* * *}$ & $0.54^{* * *}$ \\
\hline & 28 & $\begin{array}{c}\text { Informed regarding social } \\
\text { activities }\end{array}$ & $0.56^{* * *}$ & $0.55^{* * *}$ & $0.61^{* * *}$ \\
\hline & 29 & $\begin{array}{l}\text { knowledge of the school } \\
\text { curricula }\end{array}$ & $0.56^{* * *}$ & $0.53^{* * *}$ & $0.58^{* * *}$ \\
\hline & 30 & $\begin{array}{l}\text { Recognizing child's } \\
\text { classmates }\end{array}$ & $0.63^{* * *}$ & $0.60^{* * *}$ & $0.59^{* * *}$ \\
\hline & 31 & $\begin{array}{l}\text { Awareness of violence- } \\
\text { related problems }\end{array}$ & $0.56^{* * *}$ & $0.44^{* * *}$ & $0.57^{* * *}$ \\
\hline & 33 & $\begin{array}{l}\text { Being informed of decisions } \\
\text { made by the school faculty }\end{array}$ & $0.52^{* * *}$ & $0.19^{* * *}$ & $0.42^{* * *}$ \\
\hline & 36 & $\begin{array}{l}\text { Providing assistance in } \\
\text { homework assignments }\end{array}$ & $0.46^{* * *}$ & $0.42^{* * *}$ & $0.49^{* * *}$ \\
\hline & 37 & Checking child's notebooks & $0.43^{* * *}$ & $0.43^{* * *}$ & $0.45^{* * *}$ \\
\hline
\end{tabular}




\begin{tabular}{|c|c|c|c|c|c|}
\hline & 38 & $\begin{array}{c}\text { Involvement in addressing } \\
\text { discipline issues }\end{array}$ & $0.58^{* * *}$ & $0.58^{* * *}$ & $0.57^{* * *}$ \\
\hline & 39 & $\begin{array}{c}\text { Assistance in studying for } \\
\text { exams }\end{array}$ & $0.41^{* * *}$ & $0.45^{* * *}$ & $0.46^{* * *}$ \\
\hline & 40 & $\begin{array}{l}\text { Supporting the child when } \\
\text { confronting a teacher }\end{array}$ & $0.56^{* * *}$ & $0.48^{* * *}$ & $0.56^{* * *}$ \\
\hline & 41 & $\begin{array}{l}\text { Involved when child contests } \\
\text { a grade }\end{array}$ & $0.58^{* * *}$ & $0.53^{* * *}$ & $0.61^{* * *}$ \\
\hline & 42 & Review $\mathrm{f}$ graded tests & $0.42^{* * *}$ & $0.55^{* * *}$ & $0.41^{* * *}$ \\
\hline \multirow[t]{15}{*}{ Resources } & 1 & Participating in class PTA & $0.46^{* * *}$ & $0.40^{* * *}$ & $0.59^{* * *}$ \\
\hline & 2 & Participating in school PTA & $0.56^{* * *}$ & $0.53^{* * *}$ & $0.61^{* * *}$ \\
\hline & 3 & Selecting the school & $0.35^{* * *}$ & $0.23^{* * *}$ & $0.45^{* * *}$ \\
\hline & 4 & $\begin{array}{l}\text { Accompanying class } \\
\text { excursions }\end{array}$ & $0.45^{* * *}$ & $0.38^{* * *}$ & $0.54^{* * *}$ \\
\hline & 5 & Organizing school fairs & $0.48^{* * *}$ & $0.38^{* * *}$ & $0.62^{* * *}$ \\
\hline & 6 & $\begin{array}{l}\text { Providing assistance at class } \\
\text { parties }\end{array}$ & $0.57^{* * *}$ & $0.55^{* * *}$ & $0.63^{* * *}$ \\
\hline & 7 & $\begin{array}{l}\text { Attending parent-teacher } \\
\text { meetings }\end{array}$ & $0.46^{* * *}$ & $0.52^{* * *}$ & $0.39^{* * *}$ \\
\hline & 11 & Volunteer teaching & $0.55^{* * *}$ & $0.58^{* * *}$ & $0.51^{* * *}$ \\
\hline & 12 & Conducting class activities & $0.64^{* * *}$ & $0.65^{* * *}$ & $0.63^{* * *}$ \\
\hline & 13 & Class treasurer & $0.72^{* * *}$ & $0.69^{* * *}$ & $0.74^{* * *}$ \\
\hline & 14 & $\begin{array}{c}\text { Funding enrichment } \\
\text { programs and special } \\
\text { projects }\end{array}$ & $0.56^{* * *}$ & $0.67^{* * *}$ & $0.50^{* * *}$ \\
\hline & 15 & $\begin{array}{c}\text { Responsible for collecting } \\
\text { school dues }\end{array}$ & $0.60^{* * *}$ & $0.71^{* * *}$ & $0.55^{* * *}$ \\
\hline & 16 & $\begin{array}{c}\text { Providing hands-on } \\
\text { assistance in class or at } \\
\text { school }\end{array}$ & $0.65^{* * *}$ & $0.65^{* * *}$ & $0.64^{* * *}$ \\
\hline & 17 & Initiating informal activities & $0.66^{* * *}$ & $0.61^{* * *}$ & $0.68^{* * *}$ \\
\hline & 34 & $\begin{array}{l}\text { Meeting with the principal } \\
\text { regarding school issues }\end{array}$ & $0.47^{* * *}$ & $0.49^{* * *}$ & $0.49^{* * *}$ \\
\hline \multirow[t]{13}{*}{ Control } & 8 & $\begin{array}{l}\text { Visiting the class during the } \\
\text { school day }\end{array}$ & $0.28^{* * *}$ & $0.10^{*}$ & $0.30^{* * *}$ \\
\hline & 9 & Visiting the school & $0.26^{* * *}$ & 0.00 & $0.26^{* * *}$ \\
\hline & 10 & $\begin{array}{l}\text { Expressing an opinion } \\
\text { regarding the amount of } \\
\text { homework assigned }\end{array}$ & $0.33^{* * *}$ & $0.20^{* * *}$ & $0.39^{* * *}$ \\
\hline & 18 & $\begin{array}{c}\text { Participating in pedagogical } \\
\text { committees }\end{array}$ & $0.51^{* * *}$ & $0.35^{* * *}$ & $0.55^{* * *}$ \\
\hline & 19 & $\begin{array}{c}\text { Involvement in developing } \\
\text { curricula }\end{array}$ & $0.68^{* * *}$ & $0.54^{* * *}$ & $0.81^{* * *}$ \\
\hline & 20 & $\begin{array}{l}\text { Criticizing the curricula in } \\
\text { front of the management } \\
\text { team }\end{array}$ & $0.79^{* * *}$ & $0.71^{* * *}$ & $0.86^{* * *}$ \\
\hline & 21 & Hiring and firing of teachers & $0.79^{* * *}$ & $0.80^{* * *}$ & $0.73^{* * *}$ \\
\hline & 22 & Hiring and firing of principals & $0.99 * * *$ & $1.02^{* * *}$ & $0.88^{* * *}$ \\
\hline & 23 & $\begin{array}{c}\text { Assigning teachers to their } \\
\text { classes }\end{array}$ & $0.65^{* * *}$ & $0.58^{* * *}$ & $0.66^{* * *}$ \\
\hline & 24 & $\begin{array}{c}\text { Intervening in case of } \\
\text { teacher's inappropriate } \\
\text { behavior }\end{array}$ & $1.03^{* * *}$ & $1.12^{* * *}$ & $0.99^{* * *}$ \\
\hline & 25 & $\begin{array}{c}\text { Criticizing teachers' } \\
\text { performance }\end{array}$ & $0.86^{* * *}$ & $0.84^{* * *}$ & $0.85^{* * *}$ \\
\hline & 32 & $\begin{array}{l}\text { Awareness of the class's } \\
\text { scholastic achievements }\end{array}$ & $0.40^{* * *}$ & $0.19^{* * *}$ & $0.42^{* * *}$ \\
\hline & 35 & $\begin{array}{l}\text { Participating in decision- } \\
\text { making processes }\end{array}$ & $0.34^{* * *}$ & $0.36^{* * *}$ & $0.41^{* * *}$ \\
\hline
\end{tabular}


An examination of Table 4 reveals that in the Jewish sector and in the entire sample, all of the items reflect the three theoretical concepts of the parental involvement model well, with the exception of the items "class visits" (item 8) and "school visits" (item 9) in the Arab sector. The coefficient loadings for these items indicate a lesser fit with the concept of control: however, it may be considered sufficient given that the analyzed model appears stable and representative of reality. As noted, information regarding these measures in the Arab education sector are far from frequent- for a variety of reasons (which are addressed in the discussion section), hence, the theoretical contribution of this research cannot be ignored, despite the low levels of coefficient loadings. In contrast, the standard coefficient loadings for the two items "hiring and firing of principals" (item 22) and "interferes in case of teacher's inappropriate behavior" (item 24 ) were the highest in each of the groupings (.88 and .99, respectively, in the Jewish sector, 1.02 and 1.12, respectively, in the Arab sector, and .99 and 1.03, respectively for the entire sample). The standardized coefficient loadings of the items for parental involvement in pedagogy in the Jewish sector ranged from .49 to .74, in the Arab sector from .19 to .67, and in the entire sample from .41 to .74, while item 26 , "understanding social dynamics in the classroom" had the greatest validity. The standardized coefficient loadings of the items for parental involvement related to resources ranged from .59 to .74 ; in the Arab sector, from .23 to .71 ; and for the entire sample, from .35 to .72: while item 13 "responsibility for class funds" was the most valid. The standardized coefficient loadings of the items for parental involvement in control in the Jewish sector ranged.26 from .99; in the Arab sector, from .00 to 1.12; and for the entire sample from .26 to 1.03; while item 24 "parental involvement regarding inappropriate behavior of teachers" was the most valid.

As regards the differential validity, correlations between latent variables for each sector and for the entire sample indicated sufficient differential validity. Table 5 presents correlations between the three factors of the questionnaire.

Table 5. Correlations between the Three Dimensions of the Perceptions of Parental Involvement Scale

\begin{tabular}{|l|c|l|c|c|c|c|}
\hline & \multicolumn{2}{|c|}{ The Entire Sample } & \multicolumn{2}{c|}{$\begin{array}{c}\text { The Arab } \\
\text { Sector }\end{array}$} & \multicolumn{2}{c|}{$\begin{array}{c}\text { The Jewish } \\
\text { Sector }\end{array}$} \\
\hline & Resources & Pedagogy & Resources & Pedagogy & Resources & Pedagogy \\
\hline Pedagogy & $0.38^{* * *}$ & & $0.49^{* * *}$ & & $0.39^{* * *}$ & \\
\hline Control & $0.09^{* *}$ & $0.50^{* * *}$ & $0.17^{* * *}$ & $0.37^{* * *}$ & $0.11^{*}$ & $0.55^{* * *}$ \\
\hline
\end{tabular}

${ }^{*} P<.05,{ }^{* *} P<.01,{ }^{* * *} P<.001$

In summary, standardized loading coefficients for the entire sample were at an appropriate standard level, more so than for each sector separately. In general, findings regarding the fit of the measurement model and the assessment of coefficient loadings of the manifest variables indicated that the confirmatory factor analysis substantiates the validity of the research questionnaire, and thus substantiates also the theoretical bases that guided the selection of variables in both sectors, suggesting that it is a good fit for the entire population.

\section{DISCUSSION}

The main goals of the current study were to understand the differences between perceptions of parental involvement among teachers from the Jewish sector and from the Arab sector, and to validate a shared conceptualization of perceptions of parental involvement.

The findings of the study indicated an agreement across the Jewish and Arab sectors regarding the components of parental involvement. It appears that teachers from both sectors believe that parental involvement is comprised of 42 items, some of which indicate active roles while others indicate passive roles. These 42 items pertain to one of the following three major 
dimensions of parental involvement: pedagogy, resources, and control. The agreement between the sectors suggests that Arab society in general and the Arab education system in particular are undergoing processes that bring the two sectors' traditional concepts regarding education closer together. Nevertheless, significant differences were found between the sectors regarding the internal structure of these dimensions.

Agreement on the components of parental involvement may enable a common discourse intended to examine ways to improve the connection between parents and schools, by referring to a common concept of parental involvement, which is clear to all parties (Fisher, 2011). Indeed, findings of the study suggests that regardless of the sector, teachers would act to increase cooperation with parents in areas which they consider to be of major importance.

Notwithstanding the overall agreement regarding the definition of parental involvement, it is important to emphasize sectorial differences related to the components of the dimensions and their importance. Understanding this difference may lead to a broad-based public discourse on education that could include both sectors. Findings indicate that the component of control had the most significant effect $\left(\eta^{2}=.28\right)$, although more so in the Arab sector $(M=2.72)$ than in the Jewish sector $(M=1.89)$. This means that Arab teachers are beginning to see that parental involvement includes components such as expressing an opinion about the amount of homework assigned, criticizing the curriculum, and criticizing teachers' performance (see Table 2, which describes the structure of the components in the parental involvement scale). These findings suggest that Arab teachers are becoming more open towards parents and believe that parents can be involved in realms that these teachers would have found intolerable a mere decade ago (Bishara \& Shachar, 2008). It is possible that this change pertains not only to the teachers, but also to the sphere of policy makers, who are appropriating perceptions from the Jewish society regarding parental involvement. However, it is important to remember that this study examines the perceptions of teachers and does not include the perceptions of parents.

The findings obtained from analysis of data related to Arab sector teachers may be explained as constituting a stage in a process of adjusting to the Jewish society's democratization processes. Jewish society in Israel expects Arab teachers to become agents of change within their traditional society (Toren, \& Iliyan, 2013). There is indeed evidence that Arab society is transitioning from a traditional to a modern society (Ghanem, 2001). These processes allow opinions to be expressed freely and openly, even when they express disagreement and criticism, as they are based on reciprocity (Smrekar, Cohen-Vogel, \& Lee, 2010). In seeking an explanation for this phenomenon, it may be assumed that Arab teachers, who are aware of the fact that parental involvement in the Jewish sector is much greater than in the Arab sector, seek to reduce this gap, by demonstrating greater openness and allowing parental involvement to encompass more spheres of activity. It is also possible that the interaction between Jewish and Arab teachers in the context of professional development or in institutes of higher education similarly contributes to a shift in perception. In addition, there is a trend towards privatization of education in the Arab sector. These private schools, which aim to provide a solution to the failures of the Arab public education system, are receptive to parental involvement and enable parents to act as partners. The result is that public schools feel the need to take similar steps to those initiated in the private schools, one of these steps being embracing parental involvement (Keidar, 2010).

It is interesting to note that also in pedagogical areas, such as involvement in contesting a grade, checking children's notebooks, and knowledge of the school curricula, there are signs of a change in the Arab sector, and indeed Arab teachers reported a higher degree of pedagogical parental involvement $(\mathrm{M}=3.42)$ than did the Jewish teachers $(\mathrm{M}=3.15)$. Although 
the effect of this variable was small $\left(\eta^{2}=.03\right)$, it merits attention and should be explained. These findings can be related to various factors, among them an increase in the level of education in Arab society over recent years (Mustafa \& Arar, 2009), which has led to stringent criticism of the Arab education system. The criticism focuses mainly on the poor academic achievements of students, which are noticeably lower than those of students in the Jewish education sector (Abu-Asbah, 2007). We are witnessing a new emphasis on achievement in Arab society, as education is perceived as a means for socioeconomic mobility (Abu-Asbah, 2007; Mustafa \& Arar, 2009), which also explains the increased criticism of the poor academic achievements. There is still a large gap between the poor academic achievements of students in the Arab sector and the higher level of achievements among students in the Jewish sector (Ministry of Education, 2013). If teachers in the Arab sector are prepared to open the school gates to parents (or at least they report such willingness), this should be considered a propitious point in time for empowering parents in the Arab sector, particularly since -according to the teachers-- parents are demonstrating greater abilities than they did a decade ago. Policy makers in the education system should take this opportunity to develop tailored intervention programs, which can be implemented in the framework of routine parent-teacher conferences, to encourage parental involvement in pedagogy. Similar recommendations were made by studies that were conducted in other parts of the world and which focused on an Arab populations (Moosa, Karabenick, \& Adams, 2001).

In contrast to the dimensions of pedagogy and control, in which all teachers reported high levels of parental involvement, in the dimension of resources, Jewish teachers reported higher levels of parental involvement $(M=3.75)$ than did teachers from the Arab sector $(M=3.56)$. Here too, it is important to note that the effect of this dimension was relatively small $\left(\eta^{2}=.02\right)$, yet it definitely merits attention. This finding may be explained on two levels, an overt level and a covert level. On the overt level, the Jewish population possesses more resources and therefore it is likely that teachers think that this population has a greater potential for contributing in this realm, either in fiscal terms, or by foregoing a day's work. Research conducted in Israel over the years (Fisher \& Friedman, 2002, 2009; Friedman \& Fisher 2003) demonstrates that in fact there is no relationship between parents' level of income and their level of involvement in school matters. However, given that the participants in this study were the teachers rather than the parents, their opinions are pertinent to the findings, but not necessarily to reality. On the covert level, there are two aspects to be considered. The first aspect is related to Jewish teachers' preferences regarding parental involvement. Teachers from the Jewish sector apparently still prefer parents to be involved in a role of "service providers", a position from which they pose no threat to the teachers' professional status in the school. Thus, teachers prefer that parents be involved in raising funds, organizing fairs, and assisting in class festivities. Of course, they would not state this publicly, since it is not politically correct in an era that favors parental involvement; yet, covertly, this is the picture that emerges. In contrast, among teachers in the Arab sector, feelings of discrimination and inequality take center stage when relating to resources for the school (Jabareen, 2006). Hence, despite changes in the level of education of teachers and parents in the Arab sector, the most prominent reaction harks back to the feelings associated with the suffering of discrimination. Arab teachers, who share these feelings, a priori expect little from parents in terms of contribution to school resources, due to the assumption that they do not have the means. Likewise, they assume that even if parents were able to contribute to school resources, their contribution would be negligible, given the conditions in the schools.

Findings from the CFA indicate clearly that according to the teachers' perceptions, the construct of the components that make up the concept of parental involvement includes the three dimensions of pedagogy, resources, and control. These findings demonstrate that Jewish 
and Arab teachers agree on the concept and its components. When examining the broad array of 42 activities that comprise the concept of parental involvement, it appears that parents are likely to be involved in almost any area pertaining to school activities. The novelty of this finding is not only in delineating the construct of these activities, but also in presenting a perception that is multicultural, as demonstrated in the findings. In other words, regardless of any particular sector, parents are viewed as having an important role in the school's functioning. This does not mean that all parents need to or want to be involved; however, it does mean that if the parents and the school are interested in such involvement, they have plenty of room to do so and they can choose among many activities and dimensions in which they can establish involvement and partnership.

Despite the essential agreement about the components of parental involvement, there were some differences in the perceptions of teachers from the Arab and Jewish sectors. These differences can be perceived through the results of the correlation tests between the various components of each dimension, specifically, when a particular item correlates poorly with the rest of the items in the dimension (see Table 4). Although these differences are minor, they should be addressed. Thus, it was found that in the Arab sector, correlation of the item "being informed of decisions made by the school faculty" (item 33) was lower than in either the Jewish sector or in the entire sample $(\lambda=0.19)$. This finding can be explained by the fact that management teams in Arab schools have not yet reached the stage in which they cooperate with parents on decision making. In schools in the Jewish sector, the online systems that teachers use to convey information have become pivotal to the schools' functioning. Through these programs and school website, the schools provide constant reports and information regarding student attendance, behaviors, and achievements, and offer constant updates regarding school-wide decisions. Taking advantage of such programs requires not only having access to the Internet, but also having the knowledge to utilize the programs and make the most of the advantages they offer. In Israel, 85\% of mid-income residents have Internet connection, while among low income families only 55\% have Internet connection. By contrast, less than $60 \%$ of the entire Arab sector in Israel has access to the Internet, compared to $70 \%$ or more among the veteran Jewish population (Dror \& Gershon, 2012).

Another item that in the Arab sector was found to have lower correlation levels than in either the Jewish sector or in the entire sample was "selecting the school" (item 3 ) $(\lambda=0.23$ ). In the Jewish educational sector, several school districts are open to students from other districts, whereas in the Arab sector, there is almost no option to choose among schools. Therefore, it is not surprising that teachers from the Arab sector, who are not well-versed on the issue of patents selecting the school for their child, do not consider this to be an important aspect of parental involvement.

Also "conducting weekly visits to school" (item 9) $(\lambda=0.10$ ) exhibited a low level of correlation with the other items. It is possible that, despite parents' disappointment due to the gaps in academic achievements between the Jewish and Arab nation, Arab parents nevertheless respect teachers' professional status. Teachers sense this and consequently believe that parents' visits to the school and to the classroom are not necessarily directly related to parental involvement (Bishara, \& Shachar, 2008). The item "awareness of peers' academic achievements" (item 32) also exhibited a low level of correlation with the remaining items $(\lambda$ $=0.10$ ). Here too, a higher level of correlation would have been expected, particularly in light of the fact that parents in the Arab sector have demonstrated a growing awareness in recent years to the importance of academic achievements. Moreover, these parents also associate academic achievements with the completion of homework assignments (Kashti, 2011). Nevertheless, it is possible that although they are aware and make this connection, they 
attribute this importance to their own child rather than to the population of Arab students in general.

In all other items, correlations were at a medium or high level among the populations of Jewish as well as Arab teachers. This finding indicates that Jewish and Arab teachers agree in general on the components of parental involvement. It is important to note in this context that there are aspects that both sectors consider to be of great importance. In the dimension of pedagogy, a high correlation was found on the topic of "understanding social dynamics in the classroom" (item 26) among the Jewish and the Arab teachers ( $r=.74, r=.67$, respectively). Teachers in both the Jewish and in the Arab sector indicated that they wanted parents involved in this aspect. It is possible that teachers believe that parents who are involved and understand social dynamics and relationships in an era noted for the increase in verbal and physical violence among students would be involved in helping to reduce and even eradicate violence. Teachers from both sectors also indicated that they consider "responsibility for class funds" (item 13) to be related to parental involvement $(\lambda=0.74,0.67=\lambda$, respectively). This can be easily explained, given that Director General Code of Bylaws clearly attributes this responsibility to the parents and indeed the Ministry of Education welcomes this type of parental involvement (Ministry of Education, 2005). The general policy indicated in the code of bylaws related to this issue evidently seeps down to the level of the school.

A relatively new realm of parental involvement that was highly correlated with the other items was "hiring and firing of teachers" (item 21). Arab teachers and Jewish teachers consider this to be one of the aspects of parental involvement $(\lambda=0.74, \lambda=0.67$, respectively). This response seems to reflect a perspective that combines the teacher's role with the role of the parents. Is it possible that teachers would want parents to be involved in hiring and firing them? If so, what could be the reason? In the case of the current study, teachers are unionized (through a national teachers' association) and if the issue of their hiring and firing were to be dictated by parents, they would likely lose the advantage that the union affords them, namely, their job security. Hence, this finding is not easily interpreted. This statement may be an indication of social conformity, or it might reflect teachers' disappointment in the effectiveness of the teachers' associations, or their dissatisfaction with the incessant educational reforms introduced every other day; consequently, they may believe that placing the responsibility of their own hiring and firing in the hands of the parents, whose main interest is ensuring the success and contentment of the students, would only improve the situation.

The findings of this study enabled a cross-sectorial conceptualization of parental involvement, which makes it possible to use common terminology in a shared discourse, by creating a common language that is multicultural, and overcomes sectorial differences. It is important to remember that having a common language does not necessarily mean that gaps will be reduced; nevertheless, it is undoubtedly an important step towards this goal.

\section{Limitations of the Study and Suggestions for Future Studies}

This study had four major limitations:

- This sample included only elementary-school teachers. It is recommended that future studies broaden the sample to include also high-school teachers.

- The current study treated the Arab sector as a single homogenous population and did not separate between the various Arab communities in Israel, which include Christians, Muslims, Bedouins, Druze, and Circassians. Future studies should examine the question in regard to each of these communities within the Arab sector.

- The 42 activities that are included in the concept of parental involvement explained only $42 \%$ of the variance. An attempt should be made to identify additional activities, in 
order to have broader terms with which to address this issue, which is a major concern among education systems in Israel and worldwide.

- The sample included only teachers. Future studies should broaden the sample to include also parents, as was done in the earlier studies that served as the basis for the current research. A broader sample would provide the basis for a broad enough conceptualization, viable for use by policymakers, parents, teachers, and even students.

\section{References}

Abu-Asbah, K. (2005). The academic achievements of female Arab students in Israel: A factor influencing potential employment and an opportunity to improve social status. In A. Paldi (Ed.), Education --Facing the test of time 2 (pp. 627-646). Tel-Aviv: Reches Educational Projects (in Hebrew).

Abu-Asbah, K. (2007). The Arab education system in Israel-Dilemmas of a national minority. Jerusalem: The Floersheimer Institute for Policy Studies (in Hebrew) approach.

Arar, H., \& Abu-Asbah, K. (2007). Education and employment-An opportunity to change the status of Arab women in Israel. In H. Arar, \& K. Haj-Yihya (Eds.), Academics and higher education among Arabs in Israel: Issues and dilemmas (pp. 13-106). Tel-Aviv: Ramot, Tel-Aviv University (in Hebrew).

\section{Arar, K., \& Rigbi, A. (2009). To participate or not to participate? Status and perception of physical education among Muslim Arab-Israeli secondary school pupils. Sport, education and society, 14 (2), 183-202.}

Arbuckle, J. L. (2009). AMOS 17.0 user's guide. United States of America: AMOS Development Corporation. Barton, A.C., Drake, C., Perez, J.G., St. Louis, K \& George, M. (2004). Ecologies of Parent Engagement in Urban Education. Educational Researcher, 33 (4), 1-1.

Bentler, P. (1992). On the fit of models to covariances. Psychological Bulletin, 88, 588-606.

Bentler, P. M., \& Bonett, D. G. (1980). Significance tests and goodness-of-fit in the analysis of covariance structures. Psychological Bulletin, 88, 588-600.

Bishara, S., \& Shachar, H. (2008). School efficacy and the improvement of academic achievements of students in special education schools in the Arab sector and in the Jewish sector in Israel. Dapim-Journal of Educational Study and Research, 46, 159-189 (in Hebrew).

Byrne, B. M. (2001). Structural equation modelling with AMOS, basic concepts, applications, and programming. Hillsdale, New Jersey: Lawrence Erlbaum Associates

Byrne, R. M. J. (1989). Everyday reasoning with conditional sequences. Quarterly Journal of Experimental Psychology, 41(A), 141-166.

Domina, T. (2005). Leveling the home advantage: Assessing the effectiveness of parental involvement in elementary school. Sociology of Education, 78, 233-249.

Dror, Y., \& Gershon, S. (2012). Israelis in the digital age 2012. Rishon-LeZion: The College of Management (in Hebrew).

Duch, H. (2005). Redefining parent involvement in Head Start: A two-generation approach. Early Child Development and Care, 175, 23 - 35.

Eilam, B. (2002). "Passing Through" a Western-Democratic Teacher Education: The Case of Israeli Arab Teachers. Teachers College Record, 104 (8), 1656-1701.

Eilam, B. (2003). Jewish and Arab teacher trainee's orientations toward teaching- learning processes. Teacher Education, 14, 2, 169-186.

Epstein, J. L., Sanders, M. G., Simon, B. S., Salinas, K. C., Jansorn, N. R., \& Voorhis, F. L. (2002). School, family, and community partnerships: Your handbook for action. Thousand Oaks, CA: Corwin Press, Inc.

Farr, F. (2010). The discourse of teaching practice feedback: A corpus-based investigation of spoken and written modes. London: Routledge. 
Fisher, Y., Magen-Nagar, N., \& Abu-Nasra, M. (2014). Sectorial Perceptions of Parental Involvement: Similarities and Dissimilarities. Advances in Social Sciences Research Journal, 1(7), 66-85

Fisher, Y. (2011). Parental involvement. In: Y. Fisher \& I.A. Friedman (Eds.). New horizons for facet theory: Interdisciplinary Collaboration Searching for Structure in Content Spaces and Measurement (pp. 145-153).

Fisher, Y., \& Friedman, I. (2002). Identification and awareness: Foundations for parental involvement in the school's functioning. Studies in Education Administration and Organization, 26, 6-33 (in Hebrew)

Fisher, Y., \& Friedman, I. (2009). Parents and school: Reciprocity and involvement. Dapim, 47, 11-37 (in Hebrew).

Friedman, I., Horowitz, T., \& Shaliv, R. (1988). Effectiveness and school culture. Jerusalem: Henrietta Szold Institute, National Institute for Research in the Behavioral Sciences (in Hebrew).

Friedman, I. (2011). Parents-school relationship in Israel. Studies in Education Administration and Organization, 32, 237267 (in Hebrew).

Friedman, I., \& Fisher, Y. (2003). Parents and schools: Attitudes and involvement levels. Jerusalem: Henrietta Szold Institute, National Institute for Research in the Behavioral Sciences (in Hebrew).

Ghanem, A. (2001). The Palestinian-Arab minority in Israel, 1948-2000: A political study. New-York: Suny Press.

Greenbaum, Z., \& Fried, D. (Eds.). (2011). Family ties - Early childhood educational framework (K-3): A status report and recommendations. Jerusalem: The Israel Academy of Sciences and Humanities (in Hebrew).

Guttman, L. (1959). Introduction to facet design and analysis. Proceedings of the fifteenth international congress of psychology (pp. 130-132). Amsterdam: North Holland

Henderson, A.T., \& Mapp, K. L. (2002). A new wave of evidence: The impact of school, family, and community connections on student achievement. Austin, TX: Southwest Educational Development Laboratory.

Hoyle, R. H., \& Panter, A. T. (1995). Writing about structural equation models. In R. H. Hoyle (Ed.), Structural equation modeling: Concepts, issues, and applications (pp. 158-176). Thousand Oaks, CA: Sage.

Hu, L.T., \& Bentler, P.M. (1999). Cutoff criteria for hit indexes in covariance structure analysis: Conventional criteria versus new alternatives. Structural Equation Modeling: A Multidisciplinary Journal, 6, 1-55.

Jabareen, Y. (2006). Critical perspectives on Arab Palestinian education in Israel. American Behavioral Scientist, 49 (8), 1052-1074.

Jackson, D. L., Gillaspy, J. A. Jr., \& Purc-Stephenson, R. (2009). Reporting practices in confirmatory factor analysis: An overview and some recommendations. Psychological Methods, 14(1), 6-23.

Jeynes, W. (2005). A meta-analysis of the relation of parental involvement to urban elementary school student academic achievement. Urban Education, 40, 237-269.

Jeynes, W. (2007). The relationship between parental involvement and urban secondary school student academic achievement: A meta-analysis. Urban Education, 42, 82-110.

Jeynes, W. (2010). The salience of the subtle aspects of parental involvement and encouraging that involvement: Implications for school-based programs. Teachers College Record, 112 (3), 747-774.

Kashti, 0. (2011, February 22). Arab students invest more in preparing homework assignments. Ha'aretz. Retrieved from http://www.haaretz.co.il/news/education/1.1163360 (in Hebrew).

Keidar, M. (2010). Privatization trends in the Arab education sector in the first decade of the new Millennium. In A. Ichilov (Ed.), Privatization and commercialization in public education in Israel (pp. 209-236). Tel-Aviv: Ramot (in Hebrew).

Kline, R. B. (2005). Principles and practice of structural equation modeling (2nd Ed.), New York: Guilford Press.

Kostelitz, Y. (2013). A model for predicting teachers' professional self-efficacy. MA thesis, Achva Academic College (in Hebrew).

Lee, J-S., \& Bowen, N.K. (2006). Parent involvement, cultural capital, and the achievement gap among elementary school children. American Educational Research Journal, 43, 193-218.

Levy, S. (Ed.). (1994). Louis Guttman on theory and methodology: Selected writing. Dartmouth: Aldershot.

Majadla, S. (2005). Factors that affect parents' involvement in schoolwork in the Arab sector in Israel. Baqa alGharbiyye: Al-Qasemi Academic College of Education (in Hebrew). 
MacCallum, R. C., \& Austin, J. T. (2000). Applications of structural equation modeling in psychological research. Annual Review of Psychology, 51(1), 201-226.

Ministry of Education. (2004). Director General Code of Bylaw 2004/4(a). 2.3-6. (Parents' representation at school). Jerusalem (in Hebrew).

Ministry of Education. (2005). Director General Code of Bylaw 2005/4(a). 3.7-50. (Managing and collecting funds at an educational institution). Jerusalem (in Hebrew).

Ministry of Education. (2010). Director General Code of Bylaw 2005/1(a). 2.3 (Standards for school culture and climate). Jerusalem (in Hebrew).

Ministry of Education. (2013). School efficacy and growth measures. Tel-Aviv: National Authority on Measures and Assessment in Education (in Hebrew).

Moosa, S., Karabenick, S. A., \& Adams, L. (2001). Teacher Perceptions of Arab Parent Involvement in Elementary Schools. School Community Journal, 11(2), 7-26.

Mustafa, M., \& Arar, H. (2009). Minorities' access to higher education: The case of Arab society in Israel. In R. Hamaisi (Ed.), The book on Arab society in Israel: Population, society, and economy (pp. 204-226). Jerusalem: Van Leer Institute and Hakibbutz Hameuchad (in Hebrew).

Schutz, A. (2006). Home Is a Prison in the Global City: The Tragic Failure of School-Based Community Engagement Strategies. Review of Educational Research, 76 (4) 691-743.

Shye, S., \& Elizur, D. (1994). Introduction to Facet Theory. Thousand Oaks, CA: Sage Publication.

Smith, J., Woblstetter, P., Kuzin, C.A. \& De Pedro, K. (2011). Parent involvement in urban charter school: New strategies for increasing participation. The School Community Journal, 21(1), 71-94.

Smrekar, C., Cohen-Vogel, L., \& Lee, J. (2010). Mapping family -school relations in comprehensive school inform models and charter school design: A call for a new research agenda. In S.L. Christenson \& A.L. Reschly (Eds), Handbook of School-Family Partnership (pp. 380-406). New York: Routledge.

Swirski, S, \& Dagan-Buzaglo, N. (2009). Segregation, inequality, and diminishing control: Status report on Israeli education, 2009. Tel-Aviv: Adva Center-Information on Equality and Social Justice in Israel (in Hebrew).

Tabachnick, B. G., \& Fidell, L. S. (2007). Using multivariate statistics. Boston: Pearson/Allyn and Bacon.

Toren, Z., \& Iliyan, S. (2013). The problems of the beginning teacher in the Arab schools in Israel, Teaching and Teacher Education, 24 (4) 1041-1056.

Wolfson, O. (2012, October 9). Arab unemployment is double the previously estimated rate. News 1 (in Hebrew). Retrieved from http://www.news1.co.il/Archive/001-D-311163-00.html. 